Article

\title{
How does the Traditional Heavy Industry Use Ecotechnology to Achieve the Ecological Innovation Goal? Analysis Based on Expert Survey in China's Shipbuilding Industry
}

\author{
Huayan Shen ${ }^{1,2}$, Kexin Bi ${ }^{1,3, *}$, Yu Gao ${ }^{1}$ 迎 and Meisha Wang ${ }^{2}$ \\ 1 School of Economics and Management, Harbin Engineering University, Harbin 150001, China; \\ shenhuayan@hrbeu.edu.cn (H.S.); gao@hrbeu.edu.cn (Y.G.) \\ 2 School of Economics and Management, Guangzhou City Construction College, Guangzhou 510925, China; \\ 2110002@gzccc.edu.cn \\ 3 School of Management, Harbin University of Science and Technology, Harbin 150001, China \\ * Correspondence: bikexin987x@hrbeu.edu.cn
}

Received: 22 July 2020; Accepted: 14 August 2020; Published: 16 August 2020

\begin{abstract}
The traditional heavy industry creates not only economic value for societies and countries but also serious ecological and cultural damage. This type of industry is not easy to transform and upgrade because of its large-scale and complex characteristics, and its traditional management mode is being challenged. This study focused on the relation between China's current ecotechnology and ecological innovation goals. This was investigated to research a new technology and goal management method, which would promote the transformation and upgradation of traditional heavy industry. We investigated 11 shipbuilding companies with strong comprehensive capacity in China's shipbuilding bases, analyzed the viewpoints of 331 senior managers and designers with more than a decade of shipbuilding experience, and referred to the industry technical standards and literature to define types of shipbuilding ecotechnology and ecological innovation goals. Structural equation modeling was conducted to analyze the relation between them. The simulation results demonstrated that four types of ecotechnology (i.e., energy technology, shipbuilding technology, digital technology, and strategic management) represent the key factors affecting the shipbuilding ecological innovation goals. This study is of theoretical significance for traditional heavy industry, and its outcomes encourage the achievement of ecological innovation goals through the application of ecotechnology.
\end{abstract}

Keywords: heavy industry; shipbuilding industry; ecotechnology; ecological innovation goals

\section{Introduction}

A review of the historical development of heavy industry suggests that the maintenance of a certain number of heavy industry systems is the "threshold condition" for countries to achieve long-term economic growth; this can support the economic evolution of less-developed countries [1-3]. Notably, heavy industry is considered to be the most important industry with respect to the industrialization of late-developing countries, such as Germany, Japan, and China. This type of industry has achieved remarkable development because of its typical externalities and spillovers. However, because China's traditional heavy industry is a resource-intensive industry born endogenously under some objective constraints (e.g., safety and economy), a series of negative outcomes has been obtained (e.g., element price distortion, low or even exhausted resource allocation efficiency, backward market mechanisms, and deterioration of income distribution) $[4,5]$. Therefore, China's traditional heavy industry should 
urgently transform from resource-based to market-oriented management by considering both the local economic benefits and ecological-environmental protection.

Based on the global manufacturing trends and industrial restructuring, the heavy industries in developed countries attach considerable importance to the introduction of science and technology as a new factor of production and completely utilize scientific and technological innovations. Further, such industries are constantly transformed, their upgradation and ecologicalization are promoted, and knowledge-based manufacturing is encouraged.

The application of ecotechnology is the preferred strategy to realize the transformation and upgradation of the traditional heavy industry and has been an important research subject for policy makers and researchers in this field. Ecotechnology was first discussed in 1971 by Aida [6]. It is a combination of ecology and technology, originating from the development of the industrial revolution from the first generation of heavy industry to the third generation of new industrial fields. This field focuses on the symbiosis of nature and technology to establish an ecological technology system of symbiosis between nature and the human world. Many years of empirical studies have shown that ecology and technology must both be considered to obtain truly ecological innovation solutions; moreover, software technologies (e.g., culture and strategy) must be incorporated into the development of hardware technologies. The eco-social innovations aimed at environmental protection and sustainability can result in new methods, products, services, and psychological approaches [7]. Within this framework, ecotechnology is considered as the core of ecological innovation [7-9].

Forty years of ecotechnology research have suggested that the aforementioned concept is applicable to all fields of environmental management and society [10]. Since the term "ecotechnology" began to be used in research, increasingly more attention has been devoted to its definition; however, comparatively less attention has been devoted to the classification and identification of the ecotechnology types. This has resulted in ambiguity about ecotechnologies and innovative strategies among entrepreneurs. The types of technologies used in the traditional heavy industry are considerably complex; hence, in this case, it is not easy to identify the categories of ecotechnology. This increases the difficulty for companies to achieve the ecological innovation goal. The main problem to be solved currently is represented by the technical conflicts associated with the implementation of various technologies and the realization of ecological innovation. This problem can be efficiently solved via the differential symbiosis of ecotechnology [7]. Eco-technology facilitates understanding and adaptation to knowledge accumulation, capital expenditure, and infrastructures in the social-economic environment; furthermore, it can provide skills, production procedures, social norms, regulations, and lifestyles [11].

This study assumes that major types of ecotechnology considerably affect the ecological innovation goals and that the mutual influence and interaction of two technologies is the key to solving the ecological innovation problems associated with the traditional heavy industry. Related industries have used similar ideas for the research and promotion of ecotechnology [12]. Based on the expert opinion of China's shipbuilding heavy industry and empirical analysis, we identified the elements of two variables (i.e., ecotechnology and target), the internal relation between single variables, and the relation between the two variables; furthermore, we defined the internal influence law of the two variables and externalized them and verified the hypothesis of this study. Thus, this process was expected to provide a decision-making basis for the ecological innovation of the traditional heavy industry.

The post-financial crisis era has resulted in heavy pollution, continuing market downturn, order reduction, overcapacity, and capital chain rupture, which appeared during the development of the shipbuilding industry. This has resulted in an increasing desire to transform and upgrade shipbuilding companies. Ships are system engineering products with dozens of different functions. To manufacture these complex systems, it is necessary to clarify the relation between various subsystems and understand the manner in which they can be combined. With the development of technology, shipbuilding, ship supporting, and ship maintenance have been combined in a supplier network focused on ecological innovation $[13,14]$ through the modular method [15]. Meanwhile, with the increasing awareness 
for environmental protection, the shipbuilding industry has attempted to reduce the environmental impacts of maritime transport and ships and has begun to pay attention to ecological innovation [16].

However, the theoretical research on ecological innovation for the shipbuilding industry lags far behind other types of theoretical research. No rearrangement or classification of the shipbuilding ecotechnologies has been proposed yet; furthermore, the relation between ecotechnology and the ecological innovation goals is rarely mentioned. This paper describes the manner in which the application of shipbuilding ecotechnology influences the shipbuilding ecological innovation goals. First, the Delphi method was applied in combination with the literature data to create a questionnaire. The results were used to determine the key ecotechnologies and ecological innovation goals of shipbuilding; additionally, the reliability and validity of the selected variables were tested. Based on the structural equation model, we analyzed the influence trend of the shipbuilding ecotechnology on the shipbuilding ecological innovation goals and investigated the symbiosis law of the shipbuilding ecotechnology. Furthermore, we analyzed the dynamic relations between ecotechnology and the ecological innovation goals. Through this process, we formally demonstrated the implementation value of shipbuilding ecotechnology in relation to the ecological innovation goals. The outcomes of this research not only enrich the theoretical basis of ecotechnology but also provide a new technical structure and clear technical value for ecological innovation in the shipbuilding industry. Finally, they provide new ideas for the ecological transformation and upgradation of the traditional heavy industry.

\section{Theoretical Analysis}

\subsection{Research Significance of Ecological Problems in the Heavy Industry}

According to Aida, the path of ecotechnology has developed from the first generation of heavy industry (which focused only on materials) to the third generation of the new industrial field (which has focused on the collection of materials, energy, and information) [7]. A new round of technological revolution in the shipbuilding industry has resulted in increased uncertainty with respect to human life and the environment. Therefore, a comprehensive mindset is needed to develop and upgrade new solutions. Here, we investigate the effect of key ecotechnologies on the shipbuilding ecological innovation goals. It is insufficient to analyze the manner in which the realization of the goal function leads to system changes because the realization of each ecotechnology function can explain only the continuous changes driven by simple one-way deterministic causality. We decided to focus on the application of ecotechnology and the development of ecological innovation goals to demonstrate the dynamic changes in the innovation system and the symbiotic relation between different ecotechnologies.

\subsection{Definition and Application of Ecotechnology}

Haddaway found that ecotechnology changed from a buzzword to a well-defined concept through a systematic review of the related literature published between 1977 and 2017 [10].

In this study, the term ecotechnology refers to the scientific and rational use of resources, maximum possible reduction of the environmental load and operating costs, and implementation of any form of innovation technology to achieve sustainable development goals through ecological management of the operational processes. Furthermore, technical changes and social trends, such as "dematerialization," "ecological economy," or "sustainable development," indicate that the development of ecotechnology is not an autonomous process and that technical changes must be managed [17]. Therefore, in this study, we performed classification and evaluated the impact of management on ecotechnology.

Recently, the concept of ecotechnology has been widely applied in various fields, such as agriculture, transportation, and architecture [12], playing a key role in the enhancement of ecosystem service delivery, reversing biodiversity loss, and promoting ecosystem innovation [18,19]. This has highlighted the negative impacts of the traditional economic development model on the establishment of an orderly society in which humans and nature can coexist harmoniously $[20,21]$. The International 
Ecotechnology Research Centre (IERC) at Cranfield University in the UK has been implementing this type of vision.

A large number of empirical studies have been conducted on the types of ecotechnology. For example, Hideki identified four types of ecotechnology: basic or mature mechanical technology, applied information and communication technology, electronic equipment, and advanced materials [22]. Meanwhile, Aida suggested that it is necessary to rely on the comprehensive application of ecotechnologies, such as infrastructure, energy-use technology (in which users can participate in the energy decision-making), fuzzy technology, and information systems, to create a new industry related to "energy and information technology" (as in the Artificial Intelligent Systems to enhance energy efficiency(AlES) project) [7]. Therefore, ecotechnology does not only include hardware technologies related to components, equipment, and materials but also software technologies related to behaviors and processes [10]. Thus, the aforementioned studies provide the basis for the classification design of ecotechnology presented in this paper. Here, the types of ecotechnology were classified based on materials and equipment, mechanical technology, information technology, and management means.

\subsection{Shipbuilding Ecological Innovation Goal}

Drucker advocated that the most effective innovations can be derived by establishing clear goals and conducting thorough analysis and meticulous work [23]. Thus, we suggest that the realization of a shipbuilding ecological innovation strategy needs the establishment of specific and clear goals, which can be formulated by a strategic mode or quantitative means. Innovation in environmental management and policy is getting more and more attention, and has even become a specification, which indicates that it is necessary to establish the product's lifecycle environmental strategies, thus making environmental performance gradually improve. Ecological innovation is an approach that can achieve this goal [24].

By studying the interconnection between ecological innovation and ecological, economic, and social goals, we have identified four comprehensive practices aimed at ecological innovation: conducting diverse activities and successful network systems, addressing new livelihoods, and focusing on sustainable development. Ecological innovation goals can take many forms (e.g., processes, products, institutions, organizations, and marketing methods) under the consideration of environmental and economic goals [25], as also demonstrated by the policy documents of China's shipbuilding industry.

In 2020, the "Green Ship Code" of the China Classification Society changed its name into "Green Ecological Ship Code." The addition of the word "ecological" fully reflects the signs of innovation and reform within the shipbuilding system. According to the regulations, the ecological shipbuilding goals can be divided into two categories: environmental protection and ecological protection. These cover toxic substance use and emission control management, energy use and operation management, ship comfort, and environment-friendly management. In addition, the realization of ecological shipbuilding goals requires coordinated development of the social, ecological, and economic factors, and any innovative application of the shipbuilding ecotechnologies must serve this goal.

\subsection{Use of Research Methods}

Although the evolution of effective ecotechnologies can bring challenges to companies (as in the case of environmental regulations that negatively impact company profits [26]), they can also bring economic benefits [26] and improve ecological efficiency [27]. Stakeholders use resources to obtain value by presenting their existing technical expectations $[28,29]$ and communicate with the whole system to create ecological innovation goals. This process is a good example of the value of symbiotic relations. To clearly identify this process and predict the future development trend, it is necessary to refer to past cases. 


\section{Case Studies}

\subsection{Problem Description}

In this study, the Delphi method was used to identify the key factors and variables. In addition, a questionnaire was created and compiled based on the literature data and the experiences of the shipbuilding experts (i.e., senior managers and ship designers with more than a decade of experience in shipbuilding companies). Because designers have specific assignments and all the ecotechnologies and goals are represented by comprehensive indexes, we conducted four interviews with senior managers (working in the administrative, financial, human resources, and technical departments) to determine the first-level indexes. Then, to complete the questionnaire, we excluded the technologies that are less relevant to the shipbuilding ecological innovation goals and considered only the ecotechnologies that may improve or deteriorate these goals; the complete questionnaire was obtained through multiple classification, extraction, and confirmation. Nevertheless, the questionnaire was finalized only after selecting designers from various technical fields and conducting index decomposition. To avoid any fault problem between technologies, two consultants from the shipbuilding company were invited to review the final questionnaire, which included the shipbuilding ecotechnology (i.e., the independent variable) and shipbuilding ecological innovation goals (i.e., the dependent variable).

Using a five-level Likert scale, we classified the impact of shipbuilding ecotechnology on ecological innovation goals as follows: effective improvement (5), improvement (4), invalid (3), deterioration (2), and serious deterioration (1).

The shipbuilding ecological innovation goal was decomposed into three first-level goals and nine second-level goals, as shown in Figure 1.

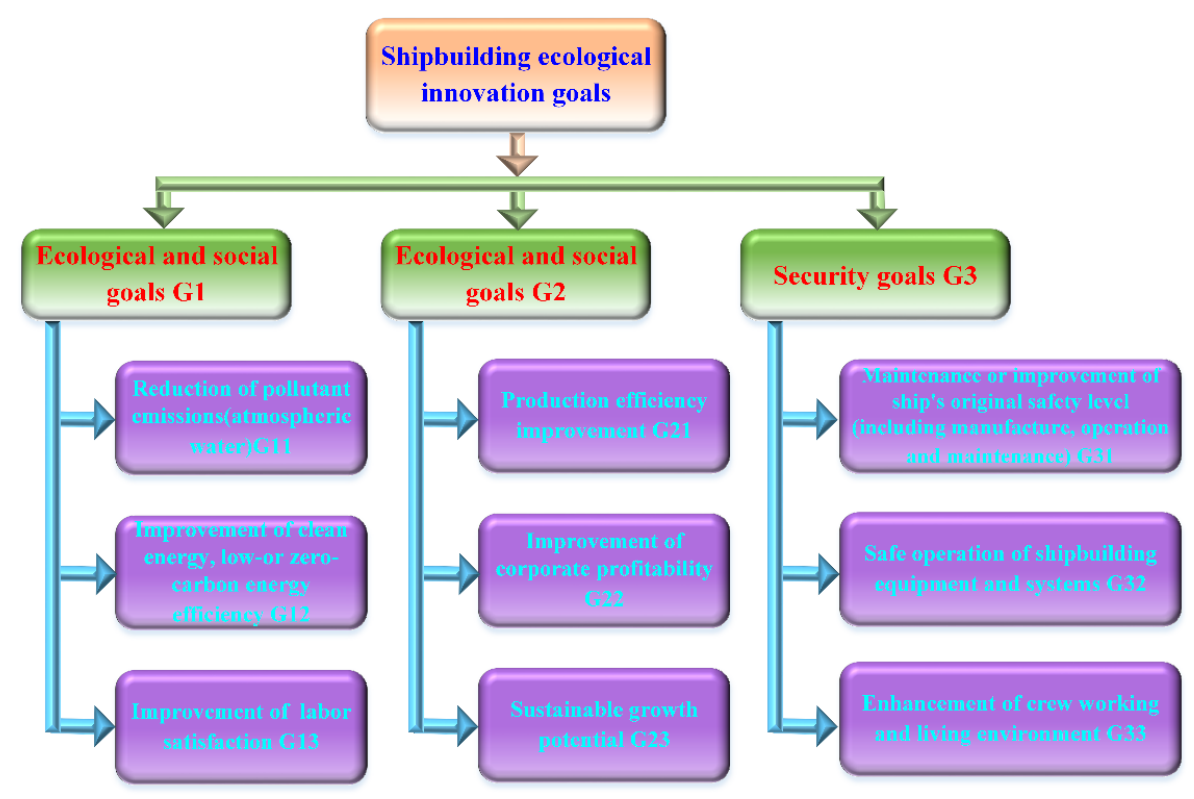

Figure 1. Decomposition of the shipbuilding ecological innovation goals.

In this study, the main shipbuilding ecotechnologies were divided into four groups: energy utilization technology, shipbuilding technology, digital technology, and strategic management. Moreover, these four groups were subdivided into 17 key ecotechnologies, which were briefly described in the questionnaire. The shipbuilding ecotechnology includes many advanced technologies. From the perspective of system structure, wind power, liquefied natural gas(LNG), hydrogen, and other renewable energy sources are the main types of energies for this group; meanwhile, ballast water systems, low sulfur oil, selective catalytic reduction (SCR), and other shipbuilding technologies are considered as its core technologies. 
The ecotechnology group was also supplemented by advanced technologies (e.g., environmental protection technology and digital technology) applied through strategic management. In this context, a composite technical network system with complementary functions can be formed (Table 1). See Appendix B for its technical definition.

Table 1. Shipbuilding ecotechnology.

\begin{tabular}{|c|c|c|c|}
\hline Ecotechnology Group & Coding & Ecotechnology Category & Coding \\
\hline \multirow{6}{*}{$\begin{array}{l}\text { Energy utilization } \\
\text { technology }\end{array}$} & \multirow{6}{*}{ A1 } & Consider pollution prevention when designing. & A11 \\
\hline & & Use renewable energy and improve energy infrastructure. & A12 \\
\hline & & Use environment-friendly materials and equipment. & A13 \\
\hline & & Increase the segment scale. & A14 \\
\hline & & Improve the level of cell manufacturing. & A15 \\
\hline & & Shorten the dock construction cycle. & A16 \\
\hline \multirow{4}{*}{ Shipbuilding technology } & \multirow{4}{*}{ A2 } & Improve the rust removal methods and processes. & A21 \\
\hline & & Improve the automated laser and welding technology. & A22 \\
\hline & & Update and upgrade the detection technology. & A23 \\
\hline & & Information feedback of the monitoring technology. & A24 \\
\hline \multirow{4}{*}{ Digital technology } & \multirow{4}{*}{ A3 } & Digitalized sample ship. & A31 \\
\hline & & Ship database construction. & A32 \\
\hline & & Data sharing between ship companies. & A33 \\
\hline & & Shipbuilding Internet of Things. & A34 \\
\hline \multirow{3}{*}{ Strategic management } & \multirow{3}{*}{ A4 } & Establish shipbuilding alliance. & A41 \\
\hline & & Improve the ship-supporting coordination capabilities. & A42 \\
\hline & & Create the product brand. & A43 \\
\hline
\end{tabular}

In this study, we investigated the impact of the shipbuilding ecotechnology on the ecological innovation goals (i.e., the impact of 17 technologies on nine goals) and explored the symbiotic relation between ecotechnologies in this process. Figure 2 shows the possible action modes between the shipbuilding ecotechnology and the ecological innovation goals.

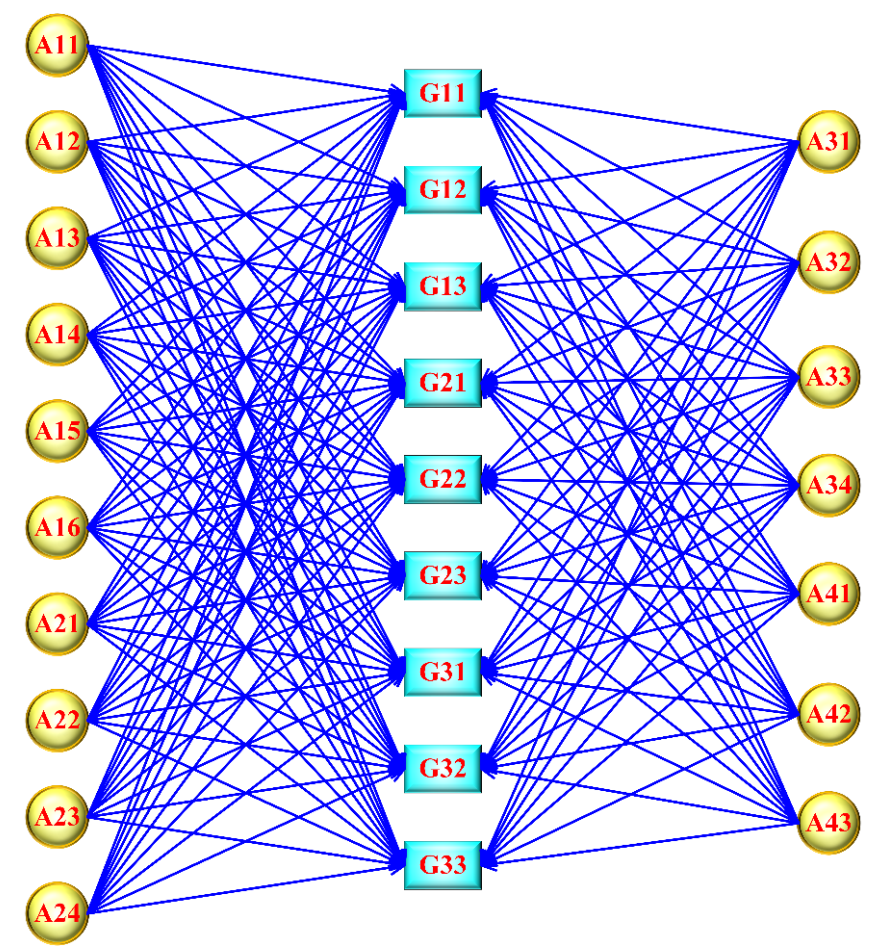

Figure 2. Possible action modes between the shipbuilding ecotechnology and the ecological innovation goals. 


\subsection{Data Collection}

We selected specific companies and surveyors for the first survey to ensure the authenticity and validity of the survey data. The survey objects were represented by 11 companies with high comprehensive shipbuilding capacity. Notably, the shipbuilding indexes of three of them ranked among the top 20 in the "China Shipbuilding Industry Yearbook" for 10 consecutive years. Moreover, these 11 companies are known to be responsible for more than $90 \%$ of China's shipbuilding production. The survey companies are listed in Appendix A. The number of investigations can be determined from the number of variables; moreover, an increase in the number of experts consulted can reduce the influence of the subjective factors. In this study, we collected a total of 331 valid questionnaires and used the Amos 22.0 software for the analyses.

\subsection{Experimental Analysis}

\subsubsection{Exploratory Factor Analysis}

To ensure data validity, we tested the quality of the questionnaire indexes (i.e., the independent variable (ecotechnology) and the dependent variable (ecological innovation goal)). First, an exploratory factor analysis was conducted on the subtechnologies of the ecotechnology group (ETG). The correspondent results are shown in Table 2.

Table 2. Kaiser-Meyer-Olkin (KMO) metric and results of Bartlett's test conducted on the ETG.

\begin{tabular}{ccc}
\hline \multicolumn{2}{c}{ KMO Metric with Sufficient Sampling } & $\mathbf{0 . 8 7 8}$ \\
\hline \multirow{3}{*}{ Bartlett's test } & Approximate chi-square & 4198.492 \\
& df & 136 \\
Sig. & 0.000 \\
\hline
\end{tabular}

Sig. = significant difference.

Table 2 shows that KMO $>7$ (0.878); thus, the variable design of the ETG was suitable for the exploratory factor analysis. Moreover, the value of Sig. obtained from Bartlett's test $(<0.001)$ indicates that the ETG had a good variable correlation.

Table 3 shows that only four components were extracted from the ETG, their principal component factors had values of $>1$, and the correspondent accumulation value was $>60 \%$ (78.811\%). These data indicate that the amount of extracted information was relatively high.

Table 3. Total variance of the ETG.

\begin{tabular}{|c|c|c|c|c|c|c|c|c|c|}
\hline \multirow{2}{*}{ Component } & \multicolumn{3}{|c|}{ Initial Eigenvalues } & \multicolumn{3}{|c|}{$\begin{array}{l}\text { Extraction Sums of Squared } \\
\text { Loadings }\end{array}$} & \multicolumn{3}{|c|}{$\begin{array}{c}\text { Rotation Sums of Squared } \\
\text { Loadings }\end{array}$} \\
\hline & Total & $\begin{array}{l}\text { Variance } \\
\%\end{array}$ & $\begin{array}{c}\text { Accumulation } \\
\%\end{array}$ & Total & $\begin{array}{l}\text { Variance } \\
\%\end{array}$ & $\underset{\%}{\text { Accumulation }}$ & Total & $\begin{array}{l}\text { Variance } \\
\%\end{array}$ & $\begin{array}{c}\text { Accumulation } \\
\%\end{array}$ \\
\hline 1 & 5.995 & 35.264 & 35.264 & 5.995 & 35.264 & 35.264 & 4.567 & 26.867 & 26.867 \\
\hline 2 & 2.919 & 17.168 & 52.432 & 2.919 & 17.168 & 52.432 & 3.318 & 19.516 & 46.383 \\
\hline 3 & 2.486 & 14.623 & 67.055 & 2.486 & 14.623 & 67.055 & 3.153 & 18.550 & 64.933 \\
\hline 4 & 1.999 & 11.756 & 78.811 & 1.999 & 11.756 & 78.811 & 2.359 & 13.878 & 78.811 \\
\hline 7 & 0.367 & 2.159 & 86.051 & & & & & & \\
\hline 8 & 0.326 & 1.919 & 87.971 & & & & & & \\
\hline 9 & 0.306 & 1.799 & 89.770 & & & & & & \\
\hline 10 & 0.299 & 1.757 & 91.526 & & & & & & \\
\hline 11 & 0.264 & 1.551 & 93.077 & & & & & & \\
\hline 12 & 0.258 & 1.518 & 94.595 & & & & & & \\
\hline 17 & 0.144 & 0.848 & 100.000 & & & & & & \\
\hline
\end{tabular}


Table 4 shows that the loading of each main factor was $>0.5$ and that there were no cross-factor loading problems; therefore, the ETG structure was better. Furthermore, an exploratory factor analysis was conducted for each sub goal of the ship ecological innovation target group (SEITG). The correspondent results are shown below.

Table 4. Rotated component matrix of the ETG.

\begin{tabular}{ccccc}
\hline & \multicolumn{4}{c}{ Component } \\
\cline { 2 - 5 } & $\mathbf{1}$ & $\mathbf{2}$ & $\mathbf{3}$ & $\mathbf{4}$ \\
\hline A15 & 0.883 & & & \\
A16 & 0.872 & & & \\
A13 & 0.865 & & & \\
A14 & 0.856 & & & \\
A12 & 0.840 & & & \\
A11 & 0.827 & & & \\
A32 & & 0.911 & & \\
A33 & & 0.906 & & \\
A31 & & 0.896 & & \\
A34 & & 0.857 & & \\
A21 & & & 0.881 & \\
A23 & & & 0.879 & \\
A22 & & & 0.858 & \\
A24 & & & 0.857 & \\
A42 & & & & 0.895 \\
A41 & & & & 0.879 \\
A43 & & & 0.835 \\
\hline
\end{tabular}

Extraction method: principal component analysis. Rotation method: Orthogonal rotation method with Kaiser standardization. The rotation converges after five iterations.

Table 5 shows that KMO $>0.7$ (0.792), indicating that the variable design of the SEITG was suitable for the exploratory factor analysis. Moreover, the value of Sig. obtained from the Bartlett's test $(<0.001)$ indicates that the SEITG had a good variable correlation.

Table 5. Kaiser-Meyer-Olkin (KMO) metric and results of the Bartlett's test conducted on the SEITG.

\begin{tabular}{ccc}
\hline \multicolumn{2}{c}{ KMO Metric with Sufficient Sampling } & $\mathbf{0 . 7 9 2}$ \\
\hline \multirow{3}{*}{ Bartlett's test } & Approximate chi-square & 1549.518 \\
& Df & 36 \\
& Sig. & 0.000 \\
\hline
\end{tabular}

Notably, only three components were extracted from the SEITG (Table 6), and their principal component factors were greater than 1; moreover, the correspondent accumulation value was $>60 \%$ $(78.902 \%)$, indicating that the amount of extracted information was high.

Table 7 shows that the values of each main factor loading were $>0.5$ and that there were no cross-factor loading problems; therefore, the ETG had a good structure. The reliability of the analysis results for ETG and SEITG can be inferred from the data shown below.

Table 8 indicated that the reliability of each dimension was $>0.7$; the ETG and SEITG had good reliability levels. Further, the total correlations of the ETG and SEITG were all $>0.5$, indicating a high attribution relation between title and dimension. After deleting the items, Cronbach's reliability was observed to be lower than the dimension reliability, indicating that the reliability of the questionnaire title was good. Thus, these results demonstrate that the questionnaire was credible and effective. 
Table 6. Total variance of the SEITG.

\begin{tabular}{|c|c|c|c|c|c|c|c|c|c|}
\hline \multirow{2}{*}{ Component } & \multicolumn{3}{|c|}{ Initial Eigenvalues } & \multicolumn{3}{|c|}{$\begin{array}{c}\text { Extraction Sums of Squared } \\
\text { Loadings }\end{array}$} & \multicolumn{3}{|c|}{$\begin{array}{l}\text { Rotation Sums of Squared } \\
\text { Loadings }\end{array}$} \\
\hline & Total & $\begin{array}{l}\text { Variance } \\
\%\end{array}$ & $\begin{array}{l}\text { Accumulation } \\
\%\end{array}$ & Total & $\begin{array}{l}\text { Variance } \\
\%\end{array}$ & $\begin{array}{l}\text { Accumulation } \\
\%\end{array}$ & Total & $\begin{array}{l}\text { Variance } \\
\%\end{array}$ & $\begin{array}{c}\text { Accumulation } \\
\%\end{array}$ \\
\hline 1 & 3.579 & 39.769 & 39.769 & 3.579 & 39.769 & 39.769 & 2.535 & 28.168 & 28.168 \\
\hline 2 & 2.241 & 24.898 & 64.667 & 2.241 & 24.898 & 64.667 & 2.355 & 26.163 & 54.331 \\
\hline 3 & 1.281 & 14.235 & 78.902 & 1.281 & 14.235 & 78.902 & 2.211 & 24.571 & 78.902 \\
\hline 4 & 0.399 & 4.432 & 83.334 & & & & & & \\
\hline 5 & 0.397 & 4.413 & 87.747 & & & & & & \\
\hline 6 & 0.342 & 3.800 & 91.548 & & & & & & \\
\hline 7 & 0.315 & 3.495 & 95.042 & & & & & & \\
\hline 8 & 0.243 & 2.703 & 97.745 & & & & & & \\
\hline 9 & 0.203 & 2.255 & 100.000 & & & & & & \\
\hline
\end{tabular}

Extraction method: principal component analysis.

Table 7. Rotated component matrix of the SEITG.

\begin{tabular}{cccccccccc}
\hline Component & G32 & G33 & G31 & G22 & G23 & G21 & G13 & G12 & G11 \\
\hline 1 & 0.924 & 0.908 & 0.905 & & & & & & \\
2 & & & & 0.882 & 0.862 & 0.835 & & & \\
3 & & & & & & & 0.850 & 0.834 & 0.816 \\
\hline
\end{tabular}

Extraction method: principal component analysis. Rotation method: Orthogonal rotation method with Kaiser standardization. The rotation converges after four iterations.

Table 8. Reliability of the analysis results for the ETC and SEITG.

\begin{tabular}{lcccc}
\hline & $\begin{array}{c}\text { Total Correlation for } \\
\text { Calibration Items }\end{array}$ & $\begin{array}{c}\text { Cronbach's Alpha after } \\
\text { Deleting Item }\end{array}$ & Cronbach's Alpha & Number of Items \\
\hline A11 & 0.784 & 0.929 & 0.937 & \\
A12 & 0.795 & 0.929 & \\
A13 & 0.827 & 0.924 & \\
A14 & 0.790 & 0.929 & \\
A15 & 0.851 & 0.921 & \\
A16 & 0.837 & 0.923 & \\
A21 & 0.791 & 0.878 & \\
A22 & 0.780 & 0.882 & \\
A23 & 0.806 & 0.873 & \\
A24 & 0.783 & 0.882 & \\
A31 & 0.833 & 0.909 & \\
A32 & 0.871 & 0.896 & \\
A33 & 0.861 & 0.899 & \\
A34 & 0.779 & 0.926 & \\
A41 & 0.756 & 0.779 & \\
A42 & 0.776 & 0.759 & \\
A43 & 0.673 & 0.855 & \\
G11 & 0.672 & 0.752 & \\
G12 & 0.677 & 0.744 & \\
G13 & 0.669 & 0.754 & \\
G21 & 0.724 & 0.822 & \\
G22 & 0.756 & 0.792 & \\
G23 & 0.740 & 0.807 & & \\
G31 & 0.797 & 0.878 & \\
G32 & 0.834 & 0.847 & \\
G33 & 0.807 & 0.870 & \\
\hline
\end{tabular}

\subsubsection{Confirmatory Factor Analysis}

After the questionnaire structure was determined via exploratory factor and reliability analyses, a confirmatory factor analysis was conducted on the ETG and SEITG. The factor loading results and the 
standardized factor loading were obtained using the Amos 22.0 software. Moreover, the aggregation validity (AVE) and composite reliability (CR) of each dimension were calculated through standardized factor loading. The correspondent results are shown below (Table 9).

Table 9. Results of the confirmatory factor loading, AVE, and CR.

\begin{tabular}{ccccccccc}
\hline Title & Dimension & Estimate & S. Estimate & S.E. & C.R. & $\boldsymbol{P}$ & AVE & CR \\
\hline A11 & & 1 & 0.809 & & & & & \\
A12 & & 1.15 & 0.821 & 0.066 & 17.358 & $* * *$ & & \\
A13 & A1 & 1.108 & 0.869 & 0.059 & 18.883 & $* * *$ & 0.716 & 0.938 \\
A14 & & 1.034 & 0.817 & 0.06 & 17.249 & $* * *$ & & \\
A15 & & 1.182 & 0.877 & 0.062 & 19.146 & $* * *$ & & \\
A16 & & 1.145 & 0.88 & 0.06 & 19.235 & $* * *$ & & \\
A21 & & 1 & 0.835 & & & & & \\
A22 & A2 & 0.942 & 0.831 & 0.053 & 17.86 & $* * *$ & & \\
A23 & & 0.974 & 0.865 & 0.052 & 18.891 & $* * *$ & 0.71 & 0.907 \\
A24 & & 1.067 & 0.839 & 0.059 & 18.098 & $* * *$ & & \\
A31 & & 1 & 0.87 & & & & & \\
A32 & A3 & 1.154 & 0.923 & 0.048 & 24.129 & $* * *$ & & \\
A33 & & 1.09 & 0.903 & 0.047 & 23.185 & $* * *$ & 0.682 & 0.896 \\
A34 & & 0.897 & 0.806 & 0.048 & 18.748 & $* * *$ & & \\
A41 & & 1 & 0.847 & & & & & \\
A42 & A4 & 1.046 & 0.881 & 0.062 & 16.852 & $* * *$ & 0.675 & 0.861 \\
A43 & & 0.767 & 0.729 & 0.054 & 14.337 & $* * *$ & & \\
G11 & & 1 & 0.788 & & & & & \\
G12 & G1 & 0.946 & 0.784 & 0.072 & 13.109 & $* * *$ & 0.602 & 0.819 \\
G13 & & 0.854 & 0.755 & 0.067 & 12.781 & $* * *$ & & \\
G21 & & 1 & 0.794 & & & & & \\
G22 & G2 & 1.147 & 0.849 & 0.071 & 16.102 & $* * *$ & 0.678 & 0.863 \\
G23 & & 1.065 & 0.826 & 0.068 & 15.692 & $* * *$ & & \\
G31 & & 1 & 0.851 & & & & & \\
G32 & G3 & 1.043 & 0.9 & 0.051 & 20.291 & $* * *$ & 0.764 & 0.901 \\
G33 & & 0.984 & 0.87 & 0.05 & 19.595 & $* * *$ & & \\
\hline
\end{tabular}

S.E. = standard error; C.R. = critical ratio.

The results suggest that the standardized factor loading values of all the parts were $>0.5$; the relevance between the title and the dimension was high in the confirmatory factor structure. The AVE values of $>0.5$ indicated that each dimension had a good aggregation validity level; additionally, the CR values of $>0.7$ indicated that each dimension had a good composite reliability level.

Table 10 shows that the model fitting CMIN/DF was <3 (1.47), and GFI, NFI, TLI, and CFI were $>0.9$; the RMSEA was $<0.05$ (0.038). Thus, the fitting results of the confirmatory factor analysis model were better, and the matching degree of the data and model was high.

Table 10. Fitting indexes of the confirmatory factor analysis model.

\begin{tabular}{cccccccc}
\hline CMIN & DF & CMIN/DF & GFI & NFI & TLI & CFI & RMSEA \\
\hline 408.748 & 278 & 1.47 & 0.914 & 0.935 & 0.974 & 0.978 & 0.038 \\
\hline
\end{tabular}

$\mathrm{CMIN}=$ chi-square; $\mathrm{DF}=$ degree of freedom; $\mathrm{CMIN} / \mathrm{DF}=$ chi-square degree of freedom ratio; $\mathrm{GFI}=$ goodness-of-fit index; NFI = normed fit index; TLI = tucker-lewis index; CFI = comparative fit index; RMSEA = root mean square error of approximation.

The analysis results in Table 11 demonstrate that A1, A2, A3, and A4 were significantly correlated with G1, G2, and G3, respectively; moreover, the correlation coefficient R values were between 0.147 and $0.457(p<0.05)$. The square root values of AVE in each dimension were added to the elements along the diagonal line and compared with the correlation coefficient. The results showed that the 
correlation coefficient between the variables was smaller than the square root values of AVE in each dimension. Therefore, the overall model can be considered to exhibit good discriminant validity.

Table 11. Discriminant validity.

\begin{tabular}{cccccccc}
\hline & A1 & A2 & A3 & A4 & G1 & G2 & G3 \\
\hline A1 & 0.846 & & & & & & \\
A2 & $0.273^{* *}$ & 0.843 & & & & & \\
A3 & $0.242^{* *}$ & $0.253^{* *}$ & 0.826 & & & & \\
A4 & $0.247^{* *}$ & 0.100 & $0.189^{* *}$ & 0.822 & & & \\
G1 & $0.403^{* *}$ & $0.220^{* *}$ & $0.260^{* *}$ & $0.286^{* *}$ & 0.776 & & \\
G2 & $0.404^{* *}$ & $0.457^{* *}$ & $0.380^{* *}$ & $0.376^{* *}$ & $0.440^{* *}$ & 0.823 & \\
G3 & $0.127^{*}$ & $0.231^{* *}$ & $0.273^{* *}$ & $0.190^{* *}$ & $0.140^{*}$ & $0.184^{* *}$ & 0.874 \\
\hline
\end{tabular}

** significant correlation at the 0.01 level. * significant correlation at the 0.05 level.

\section{Simulation Results}

The above results demonstrated that ETG and SEITG exhibited good reliability and validity, the questionnaire was credible and effective, and there was a significant correlation between the variables. Thus, we established a model, which is represented in Figure 3 below.

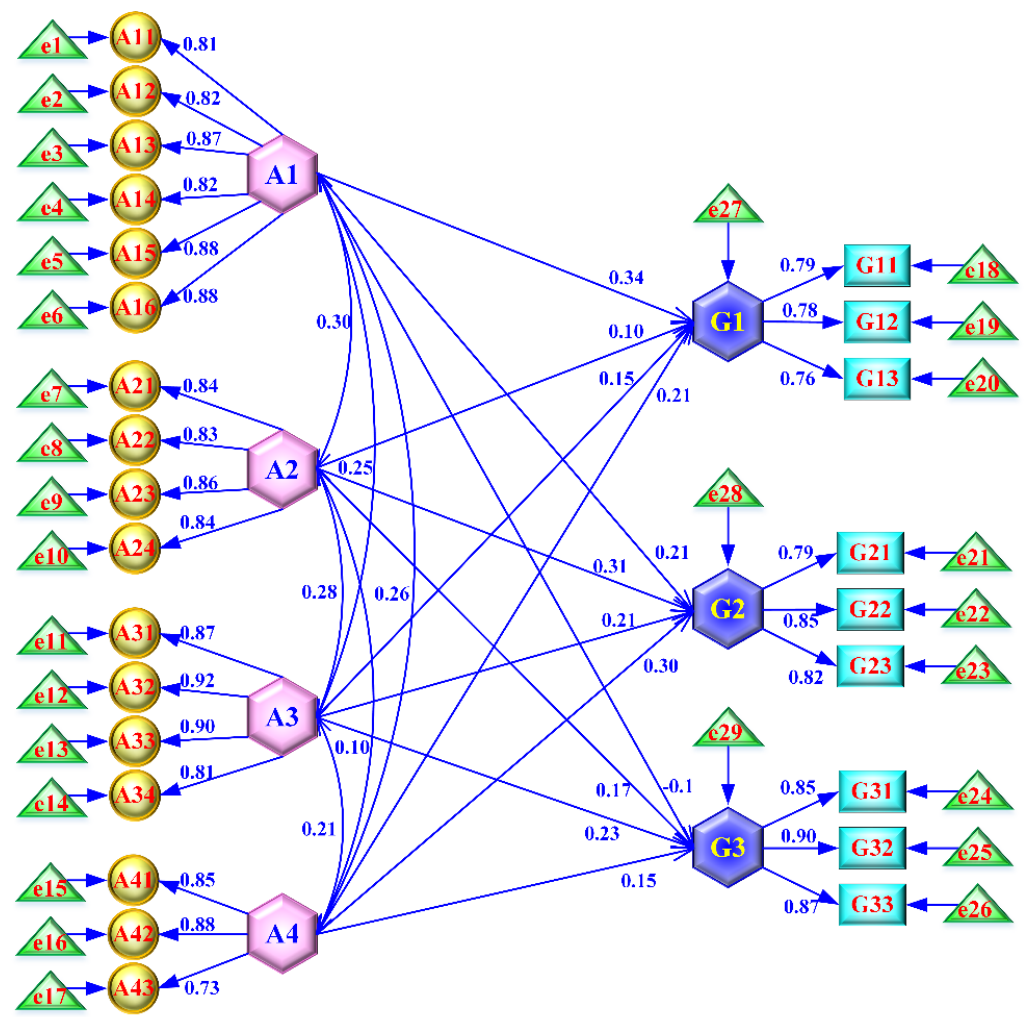

Figure 3. Standardized path coefficient diagram.

The Amos 22.0 software was used for data fitting. The corresponding fitting results are shown in Table 12.

Table 12. Fitting indexes of the path model.

\begin{tabular}{cccccccc}
\hline CMIN & DF & CMIN/DF & GFI & NFI & TLI & CFI & RMSEA \\
\hline 425.073 & 281 & 1.513 & 0.911 & 0.932 & 0.972 & 0.976 & 0.039 \\
\hline
\end{tabular}


The model fitting CMIN/DF was $<3$ (1.513); GFI, NFI, TLI, and CFI were all $>0.9$, and the RMSEA was $<0.05$ (0.039). These results indicate that the fitting results of the path model were better. The correspondent standardized path coefficients are shown in Table 13.

Table 13. Standardized path coefficients.

\begin{tabular}{cccccccc}
\hline & & & Estimate & S. Estimate & S.E. & C.R. & P \\
\hline G1 & $<---$ & A1 & 0.358 & 0.34 & 0.067 & 5.313 & $* * *$ \\
G2 & $<---$ & A1 & 0.251 & 0.212 & 0.063 & 3.981 & $* * *$ \\
G3 & $<---$ & A1 & -0.016 & -0.013 & 0.075 & -0.218 & 0.828 \\
G1 & $<---$ & A2 & 0.077 & 0.095 & 0.049 & 1.563 & 0.118 \\
G2 & $<---$ & A2 & 0.334 & 0.368 & 0.05 & 6.627 & $* * *$ \\
G3 & $<---$ & A2 & 0.157 & 0.17 & 0.058 & 2.729 & 0.006 \\
G1 & $<---$ & A3 & 0.125 & 0.147 & 0.051 & 2.439 & 0.015 \\
G2 & $<---$ & A3 & 0.203 & 0.211 & 0.05 & 4.06 & $* * *$ \\
G3 & $<---$ & A3 & 0.222 & 0.227 & 0.06 & 3.686 & $* * *$ \\
G1 & $<---$ & A4 & 0.178 & 0.215 & 0.051 & 3.507 & $* * *$ \\
G2 & $<---$ & A4 & 0.278 & 0.299 & 0.05 & 5.561 & $* * *$ \\
G3 & $<---$ & A4 & 0.141 & 0.149 & 0.058 & 2.412 & 0.016 \\
\hline \multicolumn{7}{c}{ A** $=p$-value is below 0.05.} &
\end{tabular}

Table 13 shows that the standardized path coefficient of A1 to G3 was not valid; the S-estimate value was -0.013 , and $p>0.05(0.828)$. The standardized path coefficient of A2 to G1 was also not valid, the S-estimate value was 0.095 , and $p>0.05$ (0.118). All other path coefficients were valid. The S-estimate values of A1 to G1, A2 to G2, A4 to G2, and A3 to G3 were the highest, likely because key technologies affected the realization of each of these goals.

\section{Conclusions}

In this study, we investigated the role of ecotechnology in shipbuilding companies and the manner in which these technologies promote the realization of some types of ecological innovation goals. The simulation results verified the influence of the shipbuilding ecotechnology on the ecological innovation goals (Table 14).

Table 14. Influence of shipbuilding ecotechnology on the ecological innovation goals.

\begin{tabular}{|c|c|c|c|c|}
\hline & Relation Types & & Relation Result & Goal Impact Ranking \\
\hline Energy technology & $--\rightarrow$ & $\begin{array}{c}\text { Ecological and social } \\
\text { benefit goals }\end{array}$ & Significant & 1 \\
\hline Shipbuilding technology & $-\rightarrow$ & $\begin{array}{c}\text { Ecological and social } \\
\text { benefit goals }\end{array}$ & Not significant & 4 \\
\hline Digital technology & $--\rightarrow$ & $\begin{array}{c}\text { Ecological and social } \\
\text { benefit goals }\end{array}$ & Significant & 3 \\
\hline Strategic management & $--\rightarrow$ & $\begin{array}{c}\text { Ecological and social } \\
\text { benefit goals }\end{array}$ & Significant & 2 \\
\hline Energy technology & $--\rightarrow$ & Economic benefit goals & Significant & 3 \\
\hline Shipbuilding technology & $--\rightarrow$ & Economic benefit goals & Significant & 1 \\
\hline Digital technology & $--\rightarrow$ & Economic benefit goals & Significant & 4 \\
\hline Strategic management & $--\rightarrow$ & Economic benefit goals & Significant & 2 \\
\hline Energy technology & $-\rightarrow \rightarrow$ & Security goal & Not significant & 4 \\
\hline Shipbuilding technology & $--\rightarrow$ & Security goal & Significant & 2 \\
\hline Digital technology & $--\rightarrow$ & Security goal & Significant & 1 \\
\hline Strategic management & $--\rightarrow$ & Security goal & Significant & 3 \\
\hline
\end{tabular}


(1) Energy technology, digital technology, and strategic management appeared to have an important role in promoting the realization of ecological and social benefits.

The results showed that the development goal of emerging ecotechnologies (e.g., energy technology and digital technology) was to increase the appreciation of the ecological benefits. Among these, energy technology showed the most significant impact (S-estimate $=0.34$ ). Therefore, it is necessary to strengthen the fundamental control and improvement of the ecological environment by focusing on energy, realize the mutual integration of the two technologies mentioned above according to the progress of digital technology, and promote the rapid development of ecological and intelligent dual-attribute shipbuilding. Thus, it will be possible to promote shipbuilding ecotechnology innovation and the transformation and upgradation of the shipbuilding industry structures. Further, innovation management can be conducted via strategic management for the coexistence and interaction of the two emerging technologies; thus, the shipbuilding industry can be developed according to the expected ecological goals.

However, a large number of new technologies tend to be immature during the initial application stage. This is difficult to avoid and typically results in social uncertainty. The shipbuilding technology showed no significant impact on the ecological and social benefit goals (S-estimate $=0.095$ and $p=$ $>0.05$ (0.118)). The shipbuilding technology is the pillar technology for achieving the core benefits of ships. Compared with other ecotechnologies, it requires an integrated manufacturing mode of design, production, and management, which should consider the shipbuilding costs, cycle, and quality. Today's shipbuilding industry is considerably devoted to advanced shipbuilding technology for creating high-value-added ships; however, China's shipbuilding technology is still in the initial stage of this process and has low influence on the ecological and social benefit goals. However, the ecological efficiency of the shipbuilding industry can be improved with the continuous progress of the world ship market and China's shipbuilding technology. This would promote the realization of shipbuilding industry's development goals.

(2) Energy technology, shipbuilding technology, digital technology, and strategic management play an important role in promoting the realization of economic benefits.

Economic benefits are fundamental in case of business activities. Four types of ecotechnologies considerably affected the economic benefit goal; among these, the shipbuilding technology had the most significant impact (S-estimate $=0.368$ ). The application of new processes, materials, and energy technology not only leads to products with excellent appearance and technological, and physical performances but also considerably reduces the risk of environmental damage caused by ships with great economic benefits for the shipbuilding industry. Ship technology innovation is constantly being pursued by China's shipbuilding industry. To further promote the expansion of the enterprise market, the costs must be effectively reduced by relying on the improvement of the shipbuilding technology. This would not only improve the economic benefit but also the technical performance. In particular, with the development of "Digital Shipbuilding," advanced digital and shipbuilding technologies can be comprehensively applied to the full life cycle of ships, innovation of the ship design, and production and management methods. This can also provide a unified operation and cooperation platform for shipping companies and reduce the operation costs of companies through information sharing. Strategic management provides an institutional guarantee for the implementation of the aforementioned technologies. Managers can increase the production efficiency and reduce shipbuilding costs through detailed research on the available management technologies (e.g., shipbuilding strategy, shipbuilding project planning, resource allocation, logistics management, and labor management).

It is important to consider the management disadvantages associated with China' shipbuilding industry. Both the management system and methods are extensive and can typically cause long-term management ineffectiveness. Therefore, the promotion of the development of shipbuilding management technologies is one of the goals of the shipbuilding ecological innovation. 
(3) Ship technology, digital technology, and strategic management can promote the realization of the safety protection goal, whereas the energy technology has little influence on it.

Ship technology, digital technology, and strategic management considerably affect the safety protection goal. This is especially true for digital technology (S-estimate $=0.368$ ). Ship safety protection has been mainly discussed in the context of ship manufacturing and the operation processes. Shipbuilding technology and digital technology provide good technical support for ship production, use, and maintenance. Moreover, strategic management provides the basic guarantee for safety protection (e.g., the improvement of safety systems, enforcement, safety organization, personnel allocation, safety cost, and safety education). However, the impact of energy technology on the safety protection goals was not obvious (S-estimate $=-0.013$ and $p>0.05(0.828)$ ). The reason for this is that energy technology only focuses on materials and the environment. Compared with the safety protection ranges proposed in this study, energy technology had different concerns and involved smaller modules; hence, the correspondent results were not significant.

(4) We extracted the key technologies affecting the realization of each goal.

Based on the S-estimate value, ecotechnology has different impacts on each shipbuilding ecological innovation goal. The high value of energy technology in Table 14 indicates that this is a key technology and the one with the greatest impact on the ecological and social benefit goals. The high value of the shipbuilding technology indicates that this is a key technology and the one with the greatest impact on the economic benefit goals. The high value of digital technology indicates that it is another key technology, which had the greatest impact on the safety protection goals. However, with the increasing demand of companies for ecological innovation, the importance of R\&D for new elements of ecotechnology has been increasing, leading to systematic changes in the innovation goals. When analyzing the history of the shipbuilding industry, the changes in energy, materials, and specialized fields usually correspond to system innovations. Hence, innovation can be considered to be a typical result of economic activities that require the use of scarce resources. Innovations would include not only the development of new technologies but also the development of new markets, user practices, regulations, infrastructures, and cultural significance. In addition, they would involve changes in supply (e.g., technology, knowledge, and industrial structure) and demand (e.g., user preference). The future direction of shipbuilding innovation should be green, intelligent, and ecological.

However, the impact and value of ecotechnology change dynamically. The first generation of industrial transformations was centered on heavy industry and focused on material technology; the second generation was centered on energy, and the information and circulation industries became the main industrial fields; finally, the third generation emphasized information technology, resulting in the creation of a new industrial field. Practical development proved that material technology promotes industrial change. With the recognition of ecological innovation and sustainable development, information and ecology become related to materials and ecotechnology becomes the driving force to promote industrial reforms and innovation.

Therefore, future research should explore the symbiotic structure with respect to ecotechnologies, clarify the technical standards and risks, and consider a series of structural risks to improve the design. These will represent the main means of achieving shipbuilding industry innovation as well as the transformation and upgradation of the traditional heavy industry.

Author Contributions: Writing-review and editing, data curation, H.S.; writing-original draft preparation, conceptualization, K.B.; methodology, Y.G.; formal analysis, M.W. All authors have read and agreed to the published version of the manuscript.

Funding: This research was supported by the National Natural Science Foundation of China (71774037).

Conflicts of Interest: The authors declare no conflict of interest. 
Appendix A

Table A1. Survey information.

\begin{tabular}{ccc}
\hline Area & Shipbuilding Corporation & Valid Questionnaires \\
\hline \multirow{4}{*}{ Pearl River Delta } & Guangzhou Wen chong Shipyard Company Limited (Co., Ltd.) & 35 \\
& Guangzhou Shipyard International Co., Ltd. & 36 \\
& COSCO SHIPPING Development Co., Ltd. & 34 \\
& Guangzhou Zhongchuan Longxue Shipbuilding Co., Ltd. & 26 \\
\hline \multirow{3}{*}{ Yangtze River Delta } & Shanghai Waigaoqiao Shipbuilding Co., Ltd. & 35 \\
& Jiangnan Shipyard (Group) Co. Ltd. & 30 \\
& Hudong-Zhonghua Shipbuilding (Group) Co., Ltd. & 20 \\
\hline \multirow{2}{*}{ Around Bohai Gulf Area } & Jiangsu Yangzijiang Shipbuilding Group Ltd. & 25 \\
& Bohai Shipbuilding Heavy Industry Co., Ltd. & 21 \\
& Dalian Shipbuilding Industry Co., Ltd. & 34 \\
\hline Total & Qingdao Shipyard Co., Ltd. & 35 \\
\hline
\end{tabular}

\section{Appendix B}

Table A2. Shipbuilding ecotechnology definition.

\begin{tabular}{|c|c|c|}
\hline Ecotechnology Category & Coding & Technical Explanation \\
\hline $\begin{array}{l}\text { Consider pollution prevention when } \\
\text { designing. }\end{array}$ & A11 & $\begin{array}{c}\text { Sewage treatment, ballast water system, } \\
\text { desulfurization scrubber application, SCR } \\
\text { technology }\end{array}$ \\
\hline $\begin{array}{c}\text { Use renewable energy and improve energy } \\
\text { infrastructure. }\end{array}$ & A12 & $\begin{array}{l}\text { Wind power, LNG power, hydrogen energy, } \\
\text { lithium batteries, clean energy }\end{array}$ \\
\hline $\begin{array}{c}\text { Use environment-friendly materials and } \\
\text { equipment. }\end{array}$ & A13 & $\begin{array}{l}\text { Biofuels, new materials, new coatings, indoor } \\
\text { shipbuilding technology }\end{array}$ \\
\hline Increase segment scale. & A14 & Ship standard prefabrication technique \\
\hline Improve the level of cell manufacturing. & A15 & Increase the ratio of units to total shipbuilding \\
\hline Shorten the dock construction cycle. & A16 & Advanced outfitting technology \\
\hline Improve rust removal methods and processes. & A21 & Mechanical rust removal and intelligent cleaning \\
\hline $\begin{array}{l}\text { Improve automated laser and welding } \\
\text { technology. }\end{array}$ & A22 & Laser equipment and welding robot \\
\hline Update and upgrade of detection technology. & A23 & $\begin{array}{l}\text { NDT technology (non-destructive testing } \\
\text { technology). Inspection and controlling of } \\
\text { computer, infrared thermal image detection } \\
\text { technology }\end{array}$ \\
\hline $\begin{array}{l}\text { Information feedback of monitoring } \\
\text { technology. }\end{array}$ & $\mathrm{A} 24$ & Real-time monitoring \\
\hline Digitalized sample ship. & A31 & $\begin{array}{c}\text { Digital shipbuilding, virtual reality, smart } \\
\text { shipping }\end{array}$ \\
\hline Ship database construction. & A32 & New technology, new application, ship's standard \\
\hline Data sharing between ship companies. & A33 & Technology, product, management system \\
\hline Shipbuilding Internet of Things. & A34 & $\begin{array}{l}\text { Sensor information equipment is installed into all } \\
\text { parts of the ship and combined with the Internet } \\
\text { to achieve intelligent management }\end{array}$ \\
\hline Establish shipbuilding alliance. & A41 & $\begin{array}{c}\text { The advantages and resources allocation of } \\
\text { shipbuilding enterprises }\end{array}$ \\
\hline $\begin{array}{l}\text { Improve ship-supporting coordination } \\
\text { capabilities. }\end{array}$ & A42 & $\begin{array}{c}\text { Utilization rate for localization of marine } \\
\text { equipment }\end{array}$ \\
\hline Create the product brand. & A43 & Increase the high added value of ships \\
\hline
\end{tabular}

\section{References}

1. Rosenstein-Rodan, P.N. Notes on the theory of the "Big Push". Econ. Dev. Lat. Am. 1961, 97, 57-81.

2. Murphy, K.M.; Shleifer, A.; Vishny, W.R. Industrialization and the big push. J. Political Econ. 1989, 97, 1003-1026. [CrossRef] 
3. Hirschman, A.O. The Strategy of Economic Development; Westview Press: Boulder, CO, USA, 1988.

4. Hayami, Y. Development Economics; Oxford University Press: Oxford, UK, 1997.

5. Chen, B.K.; Lin, Y.F. Development strategy, urbanization and urban-rural income gap in China. Chin. Soc. Sci. 2013, 4, 81-102.

6. Shuhei, A. An introduction to ecotechnology and its application to the AIES project. Pattern Recognit. Soc. 1995, 28, 1455-1458.

7. Franz, H.-W.; Hochgerner, J.; Howaldt, J. Challenge Social Innovation: An Introduction. In Challenge Social Innovation; Springer: Berlin/Heidelberg, Germany, 2012; Volume 10, pp. 1-16.

8. Ignacy, S. Ecotechnological productivity: A conceptual basis for the integrated management of natural resources. Soc. Sci. Inf. 1986, 25, 681-702.

9. Shuhei, A. Human Use of Human ideas-Introduction to Ecotechnology; Pergamon Press: New York, NY, USA, 1980.

10. Haddaway, N.R.; McConville, J.; Piniewski, M. How is the term 'ecotechnology' used in the research literature? A systematic review with thematic synthesis. Ecohydrol. Hydrobiol. 2018, 18, 247-261. [CrossRef]

11. Kemp, R. Technology and the transition to environmental sustainability-The problem of technological regime shifts. Futures 1994, 26, 1023-1046. [CrossRef]

12. Hu, X.N.; Si, M.Z. The method and model of ecological technology evaluation. Sustainability 2019, 11, 886. [CrossRef]

13. De Comas, F.D.C. Eco Innovative refitting technologies and processes for shipbuilding industry. Project Overview. Procedia Soc. Behav. Sci. 2012, 48, 246-255. [CrossRef]

14. Hameri, A.P.; Paatela, A. Supply network dynamics as a source of new business. Int. J. Prod. Econ. 2005, 98, 41-55. [CrossRef]

15. Engelseth, P.; Zhang, Y. Engineering roles in global maritime construction value networks. Int. J. Prod. Dev. 2012, 17, 254-276. [CrossRef]

16. Zis, T.; North, R.J.; Angeloudis, P.; Ochieng, W.Y.; Bell, M.G.H. Environmental balance of shipping emissions reduction strategies. Transp. Res. Board 2015, 2479, 25-33. [CrossRef]

17. Hekkert, M.P.; Suurs, R.A.A. Functions of innovation systems: A new approach for analyzing technological change. Technol. Forecast Soc. Chang. 2007, 74, 413-432. [CrossRef]

18. Bullock, J.M.; Aronson, J.; Newton, A.C.; Pywell, R.F.; Rey-Benayas, J.M. Restoration of ecosystem services and biodiversity: Conflicts and opportunities. Trends Ecol. Evol. 2011, 26, 541-549. [CrossRef]

19. Hobbs, R.J.; Harris, J.A. Restoration ecology: Repairing the earth's ecosystems in the new millennium. Restor. Ecol. 2001, 9, 239-246. [CrossRef]

20. UNCTAD. Technology and Innovation Report 2018: Harnessing Frontier Technologies for Sustainable Development; United Nations Publication: Geneva, Switzerland, 2018.

21. Ishak, I.; Jamaludin, R.; Abu, N.H. Green technology concept and Implementation: A brief review of current development. Adv. Sci. Lett. 2017, 23, 8558-8561. [CrossRef]

22. Hideki, K.; Masahiro, K.; Yukishige, M.; Kenji, S. An R\&D management framework for eco-technology. Sustainability 2011, 3, 1282-1301.

23. Drucker, P.F. Innovation and Entrepreneurship: Practice and Principles; Harper Business: New York, NJ, USA, 1985; (Reprint 2006).

24. O'Hare, J.A.; McAloone, T.C. Eco-innovation: The opportunities for engineering design research. In Proceedings of the DESIGN 2014-13th International Design Conference, Dubrovnik e Cavtat, Croatia, 19-22 May 2014.

25. Matthies, A.L.; Stamm, I.; Hirvilammi, T.; Närhi, K. Ecosocial innovations and their capacity to integrate ecological, economic and social sustainability transition. Sustainability 2019, 11, 2107. [CrossRef]

26. Liu, A.D.; Gu, X.S. Environmental regulation, technological progress and corporate profit: Empirical research based on the threshold panel regression. Sustainability 2020, 12, 1416. [CrossRef]

27. Triguero, A.; Moreno-Mondéjar, L.; Davia, M.A. Drivers of different types of eco-innovation in European SMEs. Ecol. Econ. 2013, 92, 25-33. [CrossRef] 
28. Mosgaard, M.; Maneschi, D. The energy renovation journey. Int. J. Innov. Sust. Dev. 2016, 10, $177-197$. [CrossRef]

29. Baraldi, E.; Gregori, G.L.; Perna, A. Network evolution and the embedding of complex technical solutions: The case of the Leaf House network. Ind. Market Manag. 2011, 40, 838-852. [CrossRef]

(C) 2020 by the authors. Licensee MDPI, Basel, Switzerland. This article is an open access article distributed under the terms and conditions of the Creative Commons Attribution (CC BY) license (http://creativecommons.org/licenses/by/4.0/). 